\title{
Serving sahibs with pony and pen: the discursive uses of 'Native authenticity'
}

\author{
David Butz \\ Department of Geography, Brock University, St Catharines, Ontario L2S 3A1, Canada; \\ e-mail: dbmarley@spartan.ac.brocku.ca
}

\author{
Kenneth I MacDonald \\ Department of Geography, University of Iowa, Iowa City, IA 52242-1316, USA; \\ e-mail: kenneth-macdonald@uiowa.edu \\ Received 20 May 1999; in revised form 12 March 2000
}

\begin{abstract}
In 1923 W Heffer \& Sons Ltd published Servant of Sahibs: A Book to be Read Aloud, an autobiographical account of Ghulam Rassul Galwan's service, from 1890 to 1901, with English and American adventurers traveling through Kashmir and Central Asia. The focus of the book on Rassul Galwan's growth through colonial labor, combined with the authenticity imposed on him and his account through a number of textual and editorial devices, allows the book to be read credibly as a text that aids the colonial establishment in utilizing a discourse of Native authenticity in support of a somewhat discredited discourse of benevolent colonial labor relations. We begin by introducing the sociopolitical context within which it was useful for such a book to be published, sponsored and described as authoritative by the colonial establishment. In the second main section, we describe the ways it was a useful authenticating text, arguing that the interplay between Rassul Galwan's narrative and the introductory and editorial comments fulfils three attributes of a convincing piece of 'Native authenticity': to identify what the text is meant to authenticate, to establish the author's authenticity as a Native voice in terms acceptable to a Western audience, and to tell the appropriate story in a way that sounds authentic to a Western ear. In the third section we demonstrate that Servant of Sahibs cannot be understood as unproblematically accommodative either to colonial constructions of transcultural labor relations or to the notion of Native authenticity. Without necessarily crediting Rassul Galwan with intent to resist, we argue that the accommodative text he helped create contains within it a tactical alternative to the very discourses it ostensibly naturalizes. This, we suggest, is characteristic of cultural products of transcultural contact zones, as well as of public transcripts of accommodation more generally. We end the paper by examining briefly (a) the possibility that Rassul Galwan's major theme of growth through colonial labor is informed less by satisfaction with his subservience to colonial masters than by interests only tangentially related to the field of domination which he is ostensibly addressing, and (b) the editor's apparent willingness to include Rassul Galwan's tactical disruptions and thus potentially recuperate those disruptions into colonial discourse.
\end{abstract}

"The ends of the earth are never the points on a map that colonists push against, enlarging their spheres of influence. On one side servants and slaves and tides of power and correspondence with the Geographical Society. On the other the first steps by a white man across a great river, the first sight (by a white eye) of a mountain that has been there forever."

Michael Ondaatje (The English Patient)

\section{Introduction}

In 1923 W Heffer \& Sons Ltd published Servant of Sahibs: A Book to be Read Aloud, an autobiographical account of Ghulam Rassul Galwan's service, from 1890 to 1901 , with English and American adventurers traveling through Kashmir and Central Asia (Galwan, 1923). Written in broken but carefully punctuated English, Servant of Sahibs tells the story of Rassul Galwan's rise from a destitute childhood, through various forms of lowly employment for Western travelers, until finally (in 1901) he becomes 
caravan overseer (bashi) for American adventurer Robert Barrett. ${ }^{(1)}$ True to its title, the book concentrates on Rassul Galwan's relations with his British and American masters and his role as mediator between Westerners and other Natives. Special attention is given to those interactions with sahibs the author feels are especially significant for his development from a 'jungly' boy to a respected and wealthy man. Except for briefly summarizing his childhood, Rassul Galwan says little about his life apart from the sahibs. Neither does he dwell on the period after 1901 other than to imply that later successes were founded on the lessons of that early formative stage in his development. ${ }^{(2)}$

Rassul Galwan wrote the book over fourteen years, at the instigation and under the close supervision of Robert Barrett, whose wife Katharine Barrett edited the final version. We are told in Katharine Barrett's editorial introduction that when Rassul Galwan entered Robert Barrett's service in 1901 he spoke less than a dozen words of English. Using "the King James Bible and a seventeenth century book of travel" as guides, Barrett taught his servant to write English and eventually to set down his story for an English-speaking public (Barrett, 1923a, page xiv). For more than a decade Rassul Galwan exchanged handwritten drafts of the developing manuscript with Barrett, who 'eliminated', 'condensed', 'rewrote', 'punctuated', and 'restored', until Rassul Galwan "at last... acquired a style with which we do not tamper" (Barrett, 1923a, page xiv).

In her editor's introduction, Katharine Barrett indicates that her husband Robert Barrett convinced Rassul Galwan to begin writing his story during their travels, as a way to overcome boredom during "periods of mere waiting, without adventure or work" (Barrett, 1923a, page xiii). She goes on to state that "the thin sheets of manuscript have been following us all over the world for fully fourteen years" (Barrett, 1923a, page xiv). We do not know how much of the book was written during the two years Rassul Galwan worked for Robert Barrett, or for what other two years writing the book "was his sole occupation" (Barrett and Barrett, 1928, page 153). We know that he worked for other travelers after 1901, including Italian geologist Filippo de Filippi in 1909 and 1913 (van Beek, 1998, page 54), maintaining frequent contact with the Barretts (Barrett and Barrett, 1928, page 153), and that he stopped adding to his manuscript in 1914 (Barrett, 1923b). Katharine Barrett did not meet Rassul Galwan in person until 1924, when she accompanied her husband on his return to Ladakh; none of the events described in Servant of Sahibs involves her. During her visit to Ladakh, in 1924 and 1925, she spent several months with Rassul Galwan, then Aksakal of Leh, while Barrett was off exploring. The Barretts were still in the region when Rassul Galwan died on 13 March 1925 (van Beek, 1998, note 15, page 64). We can infer from editorial comments that the published text includes less than a quarter of Rassul Galwan's manuscript, edited according to the demands of parsimony and the desire to construct 'a good yarn'. The book's editor's epilogue indicates that the original manuscript included more material on Rassul Galwan's travels with Barrett and subsequent employers after 1901, but that "his treatment of it is so wholly inadequate, that I have

(1) The main narrative of the book ends just before Rassul Galwan enters Barrett's service in 1901. The narrative is structured around a chronological rendering of his service with six British and one American traveler. Roughly half the book (116 pages) is devoted to "The journey of Mr. Littledale", the last of Rassul Galwan's employers before Barrett. Rassul Galwan's journey with Francis Younghusband - the best-known of his employers - is treated in a ten-page chapter, near the beginning of the book. Stylistically distinct from the main narrative is a thirty-five-page final chapter, titled "Testing the sahibs - a drama", which describes the first few months of Rassul Galwan's service with Barrett, in 1901.

(2) By the time he finished writing the book Rassul Galwan had become Aksakal of Leh, chief Native administrative assistant to the British Joint Commissioner of Ladakh. 
thought best to cut short the book at this point" (Barrett, 1923b, page 278). We are left to speculate on how Rassul Galwan's treatment of Barrett, in particular, is inadequate.

Despite the acknowledged presence of the Barretts' editorial intervention throughout the book, its introduction, written by no less an authority than Sir Francis Younghusband (who employed Rassul Galwan on one of the expeditions described in the book), presents the account as a way to "see [Natives'] ways of looking at things, and looking at us, and we understand them better and find they are after all not so very different from what we were as boys" (Younghusband, 1923, page xi). Evidently, Younghusband and the publishers, if not always Rassul Galwan or the Barretts, intended Servant of Sahibs as a glimpse at an authentic and representative Native perspective on life as a servant of colonial masters.

It is difficult to get a reliable sense of the Barretts' reasons for sponsoring and editing the book. Comments in the editor's introduction and in The Himalayan Letters of Gypsy Davy and Lady Ba (Barrett and Barrett, 1928) imply that Rassul Galwan's transformation into a published author was initially Robert Barrett's project, later shared with Katharine because she had more spare time and publishing experience. ${ }^{(3)}$ The Barretts evidently wished to give the impression that neither Servant of Sahibs nor The Himalayan Letters of Gypsy Davy and Lady Ba (1928), nor, indeed, their other similar effort (Barrett and Barrett, 1931) are meant to be taken too seriously. Nor do they identify a specific purpose in editing the book, other than to encourage an illiterate caravaneer to tell his interesting story in a language and idiom that might get read. Although this intervention may have been inspired by an attempt to do Rassul Galwan some personal good, it does not seem to have been related to a larger emancipatory politics. The Barretts permit Younghusband's paternal and patronizing introductory interpretation of the narrative, and indeed edit the manuscript in a way that invites such an interpretation. Although, as Americans, the Barretts are not colonial masters in the strictest sense, their account in The Himalayan Letters of Gypsy Davy and Lady $B a$ is replete with examples of their enthusiastic (if somewhat tonguein-cheek) adoption of the prevailing discourses and practices of colonial labor and colonial travel. In 1924 they enlist Rassul Galwan (as a friend, not a paid employee) to help them reproduce a style of travel that was more common in 1901: "Now we've twenty or more ponies for the sahib log, eight menservants, a lot of coolies carrying loads from one village to the next, and always a village headman or two escorting us" (Barrett and Barrett, 1928, page 3). They frequently liken themselves to a royal court traveling through the countryside, and seem pleased - rather than embarrassed - when they are treated like royalty, even when Rassul Galwan has roads rebuilt by villagers in preparation for their passage (see Pratt, 1992, on the 'courtly encounter'). In their own travels - as in the editing of Servant of Sahibs - the Barretts seem more interested in exploiting than dismantling colonial labor relations, whatever their formal political sympathies.

The singular focus of the book on Rassul Galwan's growth through colonial labor, combined with the authenticity imposed on him and his account through a number of textual and editorial devices, suggest that Servant of Sahibs may be read credibly as

(3) Katharine Barrett was the author or coauthor of thirteen published or self-published books, including several children's novels, two books of poetry, the memoir of a shipwreck survivor in Patagonia (with Robert), and a couple of travelogues (also with Robert). To our knowledge Robert Barrett wrote only one article independently of Katharine, although several versions of it were published in different geographical journals. Without more information on the Barrett's writing partnership it is difficult to make inferences about their "sexual politics of authorship" (Phillips, 1999, page 241). We found no evidence to support or refute the notion that Rassul Galwan's text was the site of such a sexual politics. 
a text that aids the colonial establishment in utilizing a discourse of Native authenticity in support of a somewhat discredited discourse of benevolent colonial labor relations. Our purpose is to outline such a reading. That this curious book is so obviously a transcultural representation forestalls from the outset interpretations that would accept it as either an unproblematically authentic Native account or a transparently contrived European one and allows us to foreground the ambiguities of colonialist discursive uses of Native authenticity.

The core of the problem-indeed the impossibility-of Native authenticity is articulated in Griffiths's worry that 'even when the subaltern appears to 'speak' there is a real concern as to whether what we are listening to is really a subaltern voice, or whether the subaltern is being spoken by the subject position they occupy in the larger discursive economy" (Griffiths, 1994, page 75). The latitude for texts scripted as authentically indigenous to escape their colonial discursive context is severely limited (see Bhabha, 1984; 1985; Brydon, 1991; Fee, 1989; Slemon, 1995; Spivak, 1985; 1999). This is not to suggest that the effects of subaltern speech can only be accommodative to power; rather, that resistance is "never simply a 'reversal' of power... never purely resistance, never simply there in the text or the interpretive community, but is always necessarily complicit in the apparatus it seeks to transgress" (Slemon, 1995, page 108; emphasis in original). As Young (1990, page 165, citing Spivak) suggests

"it is not a question, therefore, of being able to retrieve the lost subaltern subject as a recovered authentic voice who can be made to speak once more out of the imposed silence of history, because that subject is only constituted through the positions that have been permitted."

In A Critique of Postcolonial Reason (1999) Spivak refigures the subaltern (broadly defined) as the 'Native informant' - and therefore reshapes the problem of authenticity-arguing that in the European philosophical tradition (specifically Kant, Hegel, and Marx) the figure of the Native informant is required to theorize the Western subject (universalized as Man), even as that requirement aborts the possibility of the Native informant as subject: "Northwestern European male philosophers foreclosed the 'native informant' in order to establish the northwestern European subject as 'the same'", with the continuing effect of a "tendency to create an inchoate 'other' (often female), who is not even a native informant but a piece of material evidence once again establishing the Northwestern European subject as 'the same'" (Spivak, 1999, page 113). ${ }^{(4)}$ In this view, Rassul Galwan's value to his European audience is his Native authenticity, yet his figuring as a Native informant forecloses on the possibility of his subjectivity as an authentic Native.

In order to understand the oppositional potential of Native speech that has been recuperated by colonialist discourse as (impossibly) authentic, it is worth noting that much such speech-including the Galwan-Barrett text-is autoethnographic, a term which "refer[s] to instances in which colonized subjects undertake to represent themselves in ways that engage with the colonizers' own terms", a process which "involves partial collaboration with and appropriation of the idioms of the conqueror" (Pratt, 1992, page 7; emphasis in original). Autoethnographic texts should not be read as either authentic self-expression or inauthentic assimilation; to do either is to obliterate both their transcultural character "and their dialogic engagement with western modes of representation" (Pratt, 1992, page 102). That such speech is collaborative and

(4) Spivak summarizes her very complex argument most succinctly as follows: "I think of the 'native informant' as a name for that mark of expulsion from the name of Man... He (and occasionally she) is a blank, though generative of a text of cultural identity that only the West (or a Westernmodel discipline) could inscribe ... the native informant is needed and foreclosed" (1999, page 6; emphasis in original). 
appropriative, and deliberately engages with the colonizers' own terms, indicates its necessarily tactical character. In other words, autoethnographic texts are public transcripts: "subordinate discourse in the presence of the dominant" (Scott, 1990, page 4). (5) We see in Servant of Sahibs an instance of what Spivak describes as "a colonial subject detaching itself from the Native Informant” (1999, page ix). As Rassul Galwan's case illustrates, it is the tactical nature of this accommodation to power, for reasons that may be well beyond the colonizers' understanding, that frustrates the colonizer's desire for Native authenticity. ${ }^{(6)}$

Bhabha's conceptualizations of mimicry and hybridity are salient to understanding the ambiguity inherent in subaltern speech. He begins from the position that colonial power is never possessed entirely by the colonizer (Bhabha, 1983a, page 200), because of an ambivalence that lies at the root of the Wests' approach to subaltern " 'otherness', which is at once an object of desire and derision" (Bhabha, 1983b, page 19), expressed as a will to produce "the colonized as a fixed reality which is at once an 'other' and yet entirely knowable and visible" (Bhabha, 1983a, page 199). Mimicry is a process that emerges in the context of this ambivalence, producing in the Native a partial representation of the colonizer, similar but distorted. Although this mimicry is reassuring to the colonizer in some respects, it is also threatening and disorienting, disruptive of the power the colonizer has over representations of the other. It implies a loss of control for the colonizer and introduces "inevitable processes of counter-domination produced by a miming of the very operation of domination, with the result that the identity of colonizer and colonized becomes curiously elided" (Young, 1990, page 148). If mimicry describes how subaltern speech disrupts colonial power even at the point where it seems most accommodative to that power, but without assuming subaltern resistance, the concept of hybridity incorporates the possibility of active forms of resistance into Bhabha's formulation of the ambivalence of colonial discourse. He suggests that colonial power produces hybridized subjectivities, through which "other 'denied' knowledges enter upon the dominant discourse and estrange the basis of its authority", effectively transforming colonial discourse into something that disrupts what colonizers intended (Bhabha, 1985, page 156). Again, as with mimicry, hybridization represents a slippage between the point at which colonial texts and discourses are enunciated and their site of

(5) The extent to which Pratt's conceptualization of autoethnography (a) offers a powerful heuristic for analyzing a text such as Servant of Sahibs and (b) suffers, perhaps, from too strong an inference of intentionality is revealed in the following nuanced explication of the concept:

"Thus, if ethnographic texts are those in which European metropolitan subjects represent to themselves their others (usually their subjugated others), autoethnographic texts are representations that the so-defined others construct in response to or in dialogue with those texts. Autoethnographic texts are not, then, what are usually thought of autochthonous or 'authentic' forms of self-representation.... Rather they involve a selective collaboration with and appropriation of idioms of the metropolis or conqueror. These are merged or infiltrated to varying degrees with indigenous idioms to create self-representations to intervene in metropolitan modes of understanding.... Autoethnographic works are often addressed to both metropolitan audiences and the speakers' own community. Their reception is thus highly indeterminate. Such texts often seem to be a marginalized group's point of entry into the dominant circuits of print culture.... Autoethnographic representation often involves concrete collaborations between people, as between literate ex-slaves and abolitionist intellectuals" (Pratt, 1994, pages 28-29; emphasis in original).

We are grateful to one of the anonymous reviewers for bringing this passage to our attention.

(6) We are talking here about the ontological impossibility of Native authenticity - frustration of desire for authenticity as a textual property. This is not to say that texts cannot be accepted by metropolitan audiences as authentic expressions of a Native sensibility. As we discuss later, contemporary reviewers seemed content to acknowledge Rassul Galwan and his narrative as authentically Native, even as they sensed some ambivalence in the way he develops his theme of growth through colonial labor. 
address, but in this conceptualization the colonized utilize this slippage oppositionally, by tactically inserting repressed knowledges into colonial texts and discourses.

Each of these conceptualizations - the Native informant, transculturation, autoethnography, public transcripts, mimicry, and hybridity-casts doubt on the notion of Native authenticity. They emphasize that speech produced within a colonial discursive field is always constituted therein and never in some other space of authenticity. Subaltern texts, including those presented or received as authentic, necessarily engage with discourses of domination, either (or both) tactically (as in formulations of autoethnography, public transcripts, and hybridity) or unavoidably, as a result of the ambivalence which characterizes the discursive field of colonialism (as in Bhabha's formulation of mimicry).

This paper has four main sections. First, we introduce the sociopolitical context within which the Galwan-Barrett text was situated, as a way to discuss how it was useful for such a book to be published, sponsored, and described as authoritative by a colonial establishment which had long devalued "'secondhand', 'hearsay' and 'traditionary' Native accounts" (Ludden, 1993, page 254; see also Appadurai, 1996). We argue that by 1923 British India was suffering a legitimation crisis characterized by widespread suspicion of the benefits of colonization for Indians, and associated with specific complaints about the nature of labor relations and the treatment of Native laborers. As traditional defenders of colonial labor relations (such as Younghusband) were perceived to be losing their moral authority, other sources of legitimation became more important, including (rarely, and as a last resort) texts written by those Natives willing to verify self-congratulatory Western representations of colonial labor practices. But not all Native accounts would serve that purpose equally well. The paper's second main section indicates the ways that Servant of Sahibs was a useful authenticating text. The interplay between Rassul Galwan's narrative and the introductory and editorial comments fulfils, at least superficially, three attributes of a convincing piece of 'Native authenticity': to identify what the text is meant to authenticate, to establish the author's authenticity as a Native voice in terms acceptable to a Western audience, and to tell the appropriate story in a way that sounds authentic to a Western ear.

The first two sections avoid the theoretical problem of Rassul Galwan's authenticity as a Native voice by concentrating specifically on why and how Servant of Sahibs could be received as an authentic Native account in the service of colonial power. In the third section we return to this larger theoretical issue, not to make a case for Rassul Galwan's authenticity but rather to demonstrate that Servant of Sahibs cannot be understood as unproblematically accommodative either to colonial constructions of transcultural labor relations or to the notion of Native authenticity, despite the efforts of anyone (or everyone) involved with the production of the book. Specifically, interwoven with the dominant themes of the text are minor themes which quietly undercut both Rassul Galwan's representativeness and sincerity as a Native voice and the credibility of his pronouncements on the benevolence of colonial labor. Without necessarily crediting Rassul Galwan with any intent to resist, we argue that the accommodative text he helped create contains within it a tactical alternative to the very discourses it ostensibly naturalizes. This, we suggest, is characteristic of cultural products of transcultural contact zones, as well as of public transcripts of accommodation more generally. However, to stop at that would be to imply a false closure; to erroneously conclude that the relationship between expressions of hegemony and resistance in the text begins tidily with an initial discourse of domination and ends neatly in the tactical (and final) insertion of oppositional themes. Such a reading is problematic from two directions: it attributes too much control of the initial terms of engagement to the colonizers' discourse and too much finality to the disruption achieved by inserting 
oppositional discursive threads into that discourse. In the fourth section we examine briefly the open-endedness of these relationships by speculating on (a) the possibility that Rassul Galwan's major theme of growth through colonial labor is informed less by satisfaction with his subservience to colonial masters than by interests only tangentially related to the field of domination which he is ostensibly addressing and (b) the editors' apparent willingness to include Rassul Galwan's tactical disruptions and thus potentially recuperate those disruptions into colonial discourse.

\section{Context: beleaguered sahibs and restless labor}

Servant of Sahibs was constituted within a field of intentions and discourses extending far beyond Rassul Galwan's own interpretations of well-remembered experiences, to include his patrons and editors, the publishers and readers, and the socioeconomic and political context of British India, including Kashmir and Ladakh, in the 1920s. In this section we discuss this socioeconomic and political context in an attempt to understand why a respectable British publisher would invest in "this poor boy's book" (Galwan, 1923, page v), written as it is in an awkward and unconventional style and given that all but the most popular colonial exploration or travel narratives rarely yielded publishers a profit (MacLaren, 1995). Our main argument here is that colonial labor relations in early-20th-century India were sufficiently controversial that a book documenting a Native's experience of service for sahibs was likely to elicit considerable interest. That the book went into a second printing in 1924 is an indication that it enjoyed at least modest success. Judging from Younghusband's introductory comments, which emphasize both the authenticity of Rassul Galwan's account and his portrayal of the benefits he gained from service for colonial masters, it seems that the sponsors and publishers of the book intended it to provide an authentic Native contribution to arguments for maintaining existing colonial labor relations.

Kashmir in the early 1920 s was, like much of colonial India, a volatile place. Muslim fugitives from the princely state were among the primary instigators of demands for social reform spreading throughout India. In the decades surrounding the turn of the century they established support networks (jathas) and associations (anjuman) aimed at pressuring the government of India to undertake social reforms in the State of Jammu and Kashmir. ${ }^{(7)}$ They demanded more Muslims in the Kashmir civil service, an amended land tax, and relief from compulsory labor. Rallies in the Punjab in support of these demands suffered government surveillance, and accompanying agitation within Jammu and Kashmir in the early 1920s prompted a prohibition on political or religious speeches (Proceedings of Meeting No. 7 of the Jammu and Kashmir State Council, 4 September 1992). In Kashmir, an increasing gap between wages and the cost of living (associated with World War 1) helped focus unrest on labor issues, and especially the practice of begar $^{(8)}$ (Bamzai, 1987; Punekar and Varickayil, 1990), which had been officially abolished in Kashmir in 1893 but which continued in

(7) In 1905 the leader of the Kashmiri Muslims, Maulvi Rasoul Shah, founded the Anjuman-i-Nusratul-Islam with the object of improving the social and economic conditions of Kashmiri Muslims. The anjuman began an examination of needed social reforms in 1920 and sent a deputation to the Kashmir government in 1922 in an attempt to redress Muslim grievances (Bamzai, 1987).

(8) Begar is class-based forced or coerced labor performed in the service of public work for the state. Colonial-era begar took a variety of forms, primarily baggage carrying and road or canal building and maintenance. A contemporary definition is provided by Yule and Burnell (1903, page 80): "forced labor... a person pressed to carry a load, or do other work really or professedly for public service" (for a detailed examination of transport-related begar in Kashmir, see MacDonald, 1998). It is worth noting that Rassul Galwan was not a begari in any of the adventures described in his book, so the book cannot be described as a direct comment on the institution of begar. 
modified form well into the 1900s. As late as 1922 the Dogra government of Kashmir was still promising the in practice removal of the "great evil of Begar" as a way to attract government of India support in implementing mechanical transport schemes throughout Kashmir (Proceedings of a Meeting of the Jammu and Kashmir State Council, 2 August 1992), an indication that the State Council was aware of the colonial government's increasing sensitivity to labor conditions throughout its territories. Labor agitation by Kashmiris enjoyed the support of liberal-minded Europeans, some of whom had long condemned begar (for example, Brinkman, 1868; Thorpe, 1870), although most often in the context of proposals to annex Kashmir from what many Europeans and locals considered to be oppressive Dogra rule and populate it with white settlers. Indeed, liberal Europeans' condemnation of begar underwrote the British Resident's seizure of control of Kashmir's Dogra State government in 1889, but failed to persuade the government to redress labor injustices within the State. The missionary Arthur Neve, among others, took the matter to the India Office in August 1918 and succeeded in convincing Lord Islington (Secretary of State for India) that an inquiry into the treatment of Native laborers was demanded. Lord Islington perceived the situation as

"a case of remoteness and isolation allowing the capitalist to sweat and abuse his power, make his profit, and owing to no healthy public opinion being brought to bear on him, continue to do so with impunity. The Resident ought to look after the interests of the poor suffering people and protect them against the importunities of the capitalist - apparently this is not done by the present Resident or his staff of civil officials" (India Office Library and Records, L/P\&S/12/4261).

The atmosphere of discontent in Kashmir intensified through the war years and culminated in escalations in labor actions in the immediate postwar period (see Bamzai, 1987; Punekar and Varickayil, 1990). These local circumstances paralleled, and drew strength from, international labor activism, including the creation in 1919 of the International Labor Organization (ILO). A central focus of the ILO was the issue of labor recruitment, particularly bonded and impressed labor. Bamzai (1987, page 333) reports that ILO delegates accepted a 39-hour work week for "the cold countries of Europe and suggested a 60 hour work week for the Indian Laborers". Labor advocates and Indian workers used new ILO standards to condemn employers' practices and the colonial administration's complicity, with the result that acceptance of ILO conventions by native states was a central issue through the 1920s and 1930s and was supported by the British Trades Union Congress as well as outspoken European residents of India, including Arthur Neve and C F Andrews. A more general rise in Indian nationalism, Gandhi's 1920 call for noncooperation, the Jallianwallahbagh massacre in Amritsar in 1919, and the Assam labor unrest and mass beatings of 1921 all contributed to the consolidation of worker resistance throughout India, expressed formally in gatherings such as the All India Trade Union Congress convened at Bombay in 1920. Labor action in India throughout the 1920s resulted in the formation of the Royal Commission on Labor in India, which addressed "three great groups of conditions and problems": conditions of employment and work, the standard of life of the worker, and general questions related to workers compensation, trade unions, and trade disputes (India Office Library and Records, L/P\&S/12/4261). Although labor unrest in Dogra Kashmir developed mainly around the dissatisfaction of Muslim factory workers, there is some evidence that a general sense of heightened labor consciousness influenced colonial labor relations in the more peripheral areas of Kashmir (see MacDonald, 1994; 1998).

As Metcalf (1995) and Behdad (1994) note, servant labor was always an especially fraught issue in colonial India, because servants necessarily intruded upon the domestic lives of Europeans, making "the task of keeping India at bay... doubly difficult" 
(Metcalf, 1995, page 179). For many Europeans servants represented the most immediate personal threat from Native labor unrest. The story of an appreciative servant, edited by a woman, was likely to be particularly reassuring to other women, whose duty it was to "exercise a careful surveillance over the customs and habits of her staff" (Metcalf, 1995, page 179).

It is around this context of labor unrest within Kashmir, and a growing suspicion of colonial labor relations among Europeans, that we recognize the discursive significance of Servant of Sahibs. The book can be read as a challenge to arguments (both Native and European) in support of 'free labor' in Kashmir. It reproduces official colonial discourse on Indian Native labor, which stressed the gentleness and indulgence of masters and the zeal and loyalty of laborers or slaves. It idealizes personal bonds and draws upon European and local notions of master and servant to "stress the balance of reciprocal obligations between complementary classes" (Anderson, 1993, page 100), with the discursive result that Indian laborers seem not to be subject to unwarranted abuse at the hands of Europeans but rather were perceived to have "received considerate treatment as well as economic security in return for work" (Anderson, 1993, page 101). Rassul Galwan represents the English as the most reliable providers of this considerate treatment, through the trope of a European justice which compares favorably with local and especially Dogra (Hindu) justice, and by representing Europeans as a regular source of income. ${ }^{(9)}$ These were all difficult positions for colonial apologists to sustain following World War 1, given changes in the nature of production and concerted resistance to colonial labor conditions. In this context, the choice of Rassul Galwan - a Ladakhi - to narrate the story of a contented colonial subject has strategic importance given that in the early 20 th century Ladakh remained one of princely Kashmir's political and economic backwaters, where British presence was too small to arouse sustained anti-British sentiment, and where labor abuses were more commonly associated with the Dogra regime.

Although we cannot be certain of Rassul Galwan's or the Barretts' intentions in this regard, it is worth noting that Rassul Galwan - a literate man and the time of publication the administrative assistant to the British Joint Commissioner in Leh-was doubtless aware of these issues. Certainly the Barretts, sophisticated globetrotters and old Himalayan 'hands', were well acquainted with the general and specific issues of disaffection with colonial labor relations, despite the fact that in their own book, The Himalayan Letters of Gypsy Davy and Lady Ba, as in their editing of Rassul Galwan's narrative, they deny these issues by employing the descriptive trope of a 'topsy-turvy' and chimerical world that they enter on a pilgrimage to "the high quiet places among the simple people of an old folk tale" (Barrett and Barrett, 1928, title page).

\section{Authenticating colonial labor}

\section{Selecting an 'appropriate' authentic voice}

In the previous section we sketched the colonial discursive context within which the Galwan-Barrett narrative was produced and within which it served its sponsors. To serve colonialism well, an authenticated voice was required. Foucault's (1979) argument that literary anonymity is not tolerable because it is the author who is presumed to confirm a text's factual authenticity highlights the requirement for an identifiable

(9) Although Rassul Galwan's sympathetic portrayal of European justice was evidently interpreted by Younghusband and the Barretts as evidence of European (British) superiority, it is quite possible to interpret Rassul Galwan's comments more as a veiled criticism of Dogra justice, and Dogra rule in general, than as a direct comment of British colonialism. In Ladakh, as throughout much of Kashmir, British colonialism was perceived as a lesser evil than Dogra colonialism (despite the fact that Dogra rule at this time was underwritten by British coercive power). 
individual (a Native informant) to present a factualized Native account of colonial labor relations. This helps explain why Younghusband and the Barretts so diligently insert Rassul Galwan into their own narratives: because he lends legitimacy to their experience. The Native encounter which legitimates the exotic travel experience requires a legitimate Native, an insider's view, "the magic word that bears within itself a seal of approval" (Trinh, 1991, page 70). The identifiable, authentic acquiescent Native could help silence the complaints of racial and class oppression in a way that an anonymous or composite Native could not. Trinh (1991, page 70) suggests this is because

“the Insider's subjectivity (understood as limited affective horizon - the personal) is that very area for which the objective (understood as unbiased limitless horizonthe universal) Outsider cannot claim full authority, but thanks to which he [sic] can continue to validate his indispensable role, claiming now his due through interpretive, but still totalizing knowledge."

But not any Native will do; to operate effectively the authenticity of the Native must be represented and qualified as authoritative and appropriate and be considered safe. Moreover, it must be clear that the other has participated in generating that representation. In the case of Servant of Sahibs clarification is provided by Rassul Galwan's situation as identifiable author, by the impression of fallibility conveyed in his speech (broken English), and by the way he is constituted as a character in the narrative. ${ }^{(10)}$ These devices allow his voice to legitimize the claims of domination. An important part of the discursive use of authenticity lies in the selection of individuals who are given the partial power of voice (a power that is never fully yielded to them); who are to represent 'the authentic' (Root, 1996).

The distinction between an authorized authentic Native and the unauthorized inauthentic presupposes some outside agent capable of making the distinction. Sir Francis Younghusband (1923, page ix) fills this role in his introduction to Servant of Sahibs by declaring Rassul Galwan to be "one of themselves". Younghusband uses his authority as a well-known Himalayan explorer, officer, and administrator among those who sanction colonial authority to produce Rassul Galwan's authenticity and to provide him with a bounded space within which to speak to a Western readership. The Barretts play a similar role, but because they are relatively unknown and American they cannot sanction authority or authenticity as effectively as can Younghusband. Rather, they use their editorial prerogative to insert the authorizing voices of other European sahibs in a way that further reinforces Rassul Galwan's legitimacy as an authenticated Native. At one point, for example, when Rassul Galwan is talking about how the sepoys behaved under tense conditions, the editors add the following confirmatory footnote: "Littledale testifies that the sepoys, on this occasion, showed complete readiness to back their sahib against what must have seemed like hopeless odds" (Galwan, 1923, page 207). Similar instances of editorial authorization occur throughout the text.

The fact that Rassul Galwan is a Ladakhi (a citizen of one district within one of British India's princely states) provides him with the raw materials of authenticity. The further condition of appropriateness helps colonizers identify Natives who will be usefully authentic - in Rassul Galwan's case his training, his familiarity with European preoccupations, and his willingness to address them in a comforting and familiar way. He made himself useful by asking the right kinds of questions, making the right kinds of observations, and providing the right kinds of answers (see Trinh, 1991). An

(10) The appropriateness - and authenticating effect - of Rassul Galwan's use of broken English is informed by Spivak's remarks on one of Kipling's short stories: "the Hindustani speech of the Indian servants is painstakingly translated into archaic and awkward English. The servants' occasional forays into English are mocked in phonetic transcription. Let us call this set of moves - in effect a mark of perceiving a language as subordinate-translation-as-violation" (1999, page 162). 
introductory remark by Younghusband (1923, page ix) reveals that "in this book we get an answer to the puzzle". The puzzle?: "Why Himalayan peoples should be as ready as they are to undergo hardships, to run risks of the most serious nature... [to] readily work through long and arduous days", and why, "most wonderful of all, they are full of gratitude to their employer when they leave his service" (Younghusband, 1923, page ix). Rassul Galwan gets the questions right. Younghusband also likes how Rassul Galwan goes about getting the answers; he is impressed by Rassul Galwan's empiricism, his "close observation of men and their customs", of the way in which "men like him gaze at one with the absorbed interest of a child and take in every word one says and every move one makes - and keep it in their heads" (Younghusband, 1923, page x). Younghusband is casting Rassul Galwan as the ideal insider, "the conflict detecting and problem-solving subject who faithfully represents the Other for the master" (Trinh, 1991, page 68) in terms the master can comprehend and use and in the language of the familiar 'manners-and-customs' descriptive style (Pratt, 1986). Rassul Galwan is thus an appropriate insider who makes his masters feel comfortable in the enactment of power. Ironically, what makes Rassul Galwan's 'authentic' story so useful for colonizers' purposes is his very unrepresentativeness (and thus veiled 'inauthenticity') as a Native. The combination of benefiting singularly in career terms from involvement with the British, and doing so in one of the few small parts of British India (and Kashmir) with little anti-British sentiment, allowed him to present a more positive rendering of British colonial labor than most of his compatriots would have been likely to construct.

Any danger that Rassul Galwan might have slipped passages into the narrative that were inappropriate to the interests of colonial power was diminished by the twenty years the Barretts had to discipline the text's production. ${ }^{(1)}$ A glimpse at the unequal negotiation between Rassul Galwan and the Barretts involved in producing the text is provided by Katharine Barrett in The Himalayan Letters of Gypsy Davy and Lady Ba, when she remembers the day "Rassul's book" first arrived in Leh. She describes how Rassul claims to have omitted certain events because "as asham [portentous] matter, good for telling, not good for book" (Barrett and Barrett, 1928, page 153). She also reveals the extent to which Rassul Galwan developed his style to match the expectations of his patrons and audience, when she claims that his "sense of structure [was] conscious. When one of his stories appeared so rambling that the Sahib grew restless, he said: 'Sir, you stay. After, come very sweet this story. But in story coming many branch", (Barrett and Barrett, 1928, page 153). The apparent boredom of the sahib guided Rassul Galwan to structure narratives acceptable to a European audience in categories familiar to that audience. ${ }^{(12)}$ Indeed, Katharine Barrett remarked, rather naively, "I had supposed I was doing all the editing, but I find he was not so undiscriminating as I supposed" (Barrett and Barrett, 1928, page 153). Still, when Rassul Galwan finally saw the finished book he was surprised by the extent to which his story was edited by the Barretts:

"I [Katharine Barrett] explained steadily that only a little of his story was to be printed. He struggled with the idea, but couldn't quite take it in ... . He would start: 'That man, Khalik Hussein, who was cook for Himbro Sahib'-breaking off, watching my unresponsive face, is in my book madam'. A pause. 'Is in my book

(11) That is not to say that comments need be unswervingly complimentary to colonialism or particular colonial masters to be appropriate. Indeed, a few critical comments sprinkled throughout the text may help establish its (and the narrator's) authenticity, in addition to reinforcing the arbitrariness (and therefore impressiveness) of colonizers' power over Natives.

(12) For discussion of the responsiveness of indigenous voices to colonizers' perceived expectations, see Adorno (1982), Klor de Alva (1992), and Salomon (1982). 
madam?' Insistently: 'Is in my book madam. Must to be in my book'" (Barrett and

Barrett, 1928, page 153; emphasis added).

Rassul Galwan's reaction to this conversation may not have been entirely innocent: "'I thinking madam, is right, my book and title. I was "Servant of Sahibs". Is right matter" (Barrett and Barrett, 1928, page 153).

We see here the extent to which Rassul Galwan was appropriate because he consented to be appropriated, albeit under false pretenses and a degree of coercion. In the end, his authorization as an appropriate, authentic Native took place after a long and controlled process of disciplining in which he was constructed, with his own complicity, as the ideal insider; one who eventually wrote a manuscript that could be edited into an appropriate reflection of the colonizer's self-image. Had he not emerged as a reliable, appropriate Native, his supposed authenticity would have been useless to colonial power (see Paster, 1989).

Despite the constraints placed on Rassul Galwan's narrative it still exists as a type of limited decentralization of authority, partially a production by a "fantasized Other as authoritative subject of an other knowledge" (Trinh, 1991, page 186). This creates a dilemma in constituting Rassul Galwan as an authentic voice and with attempting to use an authentic Native voice within a colonial discourse of the other. For Rassul Galwan to be an appropriate authentic Native voice he had to be constructed as a Native unlike other Natives - more specifically as a Ladakhi unlike other Ladakhis - a construction which confounds his position as authentic within the colonial production of knowledge. When he assumed the authority to represent others he immediately occupied a liminal position of looking in from the outside in order to speak out from the inside. As he mimicked Europeans, Rassul Galwan was caught in the tense situation of being simultaneously inside and outside, of being both deceptive insider and deceptive outsider, and in that position he resorts to textual strategies that "suspend meaning and resist closure" (Trinh, 1991, page 74), itself a tactic that is liable to recuperation by more dominant discourses.

\section{Telling an appropriate 'authentic' story}

Servant of Sahibs develops a number of themes that tell the appropriate story in a way that might be expected to sound authentic to the colonizer's ear. We focus here on the most important and encompassing of these: that sahibs' domination of Natives is natural, inevitable, and, beyond that, good, just, and appropriate; and that attentive Natives such as Rassul Galwan can civilize and enrich themselves through transcultural interactions with sahibs, as structured through colonial labor. A third, minor, theme that runs across the grain of the two dominant themes-that European power is on occasion exercised quite brutally, coercively, arbitrarily, and impetuously - is discussed in the next two sections.

The text uses the authentic voice of Rassul Galwan to provide insight into his moral and material evolution from a young Ladakhi boy, desirous of acquiring knowledge for the sake of material gain and advancement, into a fully evolved colonial subject ('mimic-man') who reaches the pinnacle of local administrative success as the Assistant to the British Joint Commissioner in Leh. ${ }^{(13)}$ The editors conspicuously chart Rassul Galwan's development through descriptions of various events and journeys

(13) The foundation for this narrative of evolution is provided in the numerous instances where the boy Rassul is characterized as more intelligent, independent, cleaner, and more moral than other Ladakhi boys. In one case he 'others' himself through the trope of exceptional intelligence: "One man said: 'Look this house and garden. What boy made them, that boy very clever'. I did hear this. Then I go near. They say: 'Who built it? We suppose you built it. Those brick, with what you make them?' Then I showed that match box. All things showed them. They said: 'You are very wise a boy'. Then my felt was happy" (Galwan, 1923, page 6). 
which "mark successive steps in the steady progress of the 'poor winnowing-woman's son' toward 'rank and honor" (editorial comment, in Galwan, 1923, page 84). The text focuses on the development of character traits pertinent to colonial endeavors and which confirmed dominant perceptions of the moral influence of European rule. At one point, the editors state that Rassul Galwan's account of a journey is included "practically entire" because it "shows, at a high point of development, Rassul's resourcefulness and devotion" (editorial comment, in Galwan, 1923, page 128). This was not a 'natural' development, however, but one that was nurtured by sahibs who "early appreciated the possibilities of their man, and gave him opportunities to develop them" (editorial comment, in Galwan, 1923, page 84).

Rassul Galwan's narrative supports this trope of evolution through colonial labor by presenting an abundance of parables of power. In a section called "The breaking cup", for example, Rassul Galwan recounts how he accidentally broke a sahib's cup and was afraid to confess. When he finally admits his wrongdoing he learns that telling the truth brings praise and not abuse: "Because sahib did not get angry I tell true matter... After, munshi said to me: 'sahib is not angry about that cup, but you must be careful, not break things'. I said: 'Yes, sir'" (Galwan, 1923, page 61). The benevolence of European justice is revealed, and Rassul Galwan learns the improving lesson that the truth will set him free. These lessons had an effect. According to the narrative, as Rassul Galwan aged and gained experience with sahibs, he progressed from being in constant conflict with them to experiencing increasing conflict with his fellow Ladakhi servants. The transition hinges on his growing appreciation of European justice. Having been subjected to it he duly recognizes its inherent fairness and is able to equate its Victorian 'spare the rod, spoil the child' rationale with the way his mother treated him as a child; a coincidence which entrenches his support of the paternal ideology of colonialism. In his representation of European justice Rassul Galwan validates the colonial self-image, including the civilizing effects of colonial rule. Having developed an appreciation of European justice, Rassul Galwan applied it to evaluate other transcultural encounters. When working for Dogra masters, for example, he was "very sorry for the justice of Hindu people" (Galwan, 1923, page 43). When the Hindu merchants failed to pay him the agreed rate, he threatened to complain to the British Joint Commissioner in Leh. Here the text positions Europe in the role of patron and mediator, confirming and legitimizing a European self-perception of effective action and justice. Beyond that, it invokes reputation; such is Britain's reputation for justice that order is maintained merely by invoking symbols of British authority. Rassul Galwan's final line before leaving the "bad luck journey with Hindus" is notable. He derides the Hindu merchants for their bad treatment of him and then refers for comparison not to his own treatment by Europeans, which was occasionally abusive, but rather to European justice: "The European justice is good. For this God has given them power" (Galwan, 1923, page 48).

Throughout Rassul Galwan's narrative the benevolence of what he calls European justice and the inevitability and potential violence of British power go hand in hand. Although Rassul's admissions of wrongdoing were immediately forgiven, the threat of future violence remained. For example, after lighting a fire which spoiled a sahib's hunting opportunity, Rassul Galwan confessed to his misdeed: "Sahib said: 'You told true. Therefore I pardon you this time. If you do like this again, then I will beat you'. I said: 'Yes, sir'" (Galwan, 1923, page 91). This combination of power, justice, and the threat of violence is valorized in his descriptions of encounters with Russians. In two such encounters, Rassul Galwan effectively confirms Britain's self-image as omnipotent international police by invoking the authority of the emperor-protector. At one point, he recounts what happened when his party saw strange hoofprints on the Pamir: 
"I said: 'These must be of Russian tracks'. Ramzan was afraid and said: 'the Russians will kill us'. I said: 'No, no they cannot kill us. Our Emperor King is very strong. How can they kill us?'” (Galwan, 1923, page 70). Again, on encountering Russians who threaten to kill him, Rassul cautions them:

" 'You people could not kill me. Our government is very strong. I am the subject of the

English. But our government's custom has been light; never to kill a man without fault. I am a very little man, but if you kill me, then our government must search the bloodtracks of even a little man, when they hear it'" (Galwan, 1923, page 71).

One way the text illustrates the glory, inevitability, and benevolence of British power, and shares in it, is by frequently describing what Pratt (1986, page 150) terms 'courtly encounters': conventional scenes in which "the European male portrays himself arriving in a village and presenting himself to the local patriarch and court" largely as a display of power. Rassul Galwan's awe-struck description of the meeting between Francis Younghusband and the Amban of Yarkand confirms both the power relations inherent in the courtly encounter and the self-image of colonial heroes such as Younghusband: "In all bazaar the people standing up for sahibs. I felt happy to be coming with so big a man" (Galwan, 1923, page 35). He also elevates his own status by associating himself with this 'big man', an association that contributes to his own moral development. Later in the book, for example, when fellow servants adominish him for treating Chinese merchants and travellers with compassion, he replies: "It is not good to show bad temper. That is bad men's work. Then they would never think us big men. If we show good temper, they must think us big men's servants" (Galwan, 1923, page 136). The text confirms sahibs' self-image and at the same time aligns Rassul Galwan with the masters and differentiates him from his peers. Indeed, Rassul Galwan consistently associates himself with his masters and continually and progressively distances himself from fellow laborers and servants. Paraphrasing from Gikandi's analysis of imperial femininity, it seems that by stressing his identification with European masters in the field of empire Rassul Galwan is able simultaneously to do two things: both to counter and confirm the conventional image of Native servants and to "establish empathy with the implied reader, clearly defined as someone who shares [with Rassul Galwan] the dominant moral and social codes of the period" (Gikandi, 1996, page 136). Following Gikandi, it is possible to see this strategy as an attempt to solve crises of both identity and representation. In both cases inclusion in one register of dominant discourse requires a recursive and distancing manoeuver in another register.

Throughout the text, justice, power, and violence are mediated by the goodness and parental concern of sahibs toward their servants. For justice to be good, for its dispensation to be fair, sahibs must be good. Already in the preface to the book, Rassul Galwan typifies his sahibs in a way that must have made their hearts swell: "Their goodness and faithfulness I do very much remember" (Galwan, 1923, page v). This typification is also an act of mimicry; a reversal of any number of European descriptions of Natives, including some that were extracted and appended to Rassul Galwan's narrative as editorial comments. Lord Dunmore, for example, says of Rassul Galwan and his brethren in a paper read to the Royal Geographical Society, "A better set of men, hardier or more willing, I have never met with" (editorial comment, in Galwan, 1923, page 75). Part of the goodness of Rassul Galwan's colonial masters stems from their parental concern for Native servants' welfare, a concern that Rassul Galwan repays with humility, honesty, and loyalty, each of which naturalizes colonial power asymmetries. ${ }^{(14)}$

(14) At one point Rassul Galwan is addressed by a sahib as 'Mr Rassul'. After seeking clarification on the meaning of Mr he responds, "I am not a Mr. I am a poor servant. Don't call me Mr." (Galwan, 1923, page 162). 
For example, he describes Indians not only as children of the Queen Empress but of all sahibs. In speaking to his fellow servants, he offers sage advice:

"I said among them: 'These sahibs are very big men. We must need do good work, and truth in everything.... We will find good money, and beside that, sahib write our name in his book, and the Government be kind to us'. And I said: 'We must think Mrs. Littledale is as our mother, and Mr. Littledale as our father and we all their children. We must work from inside heart'" (Galwan, 1923, page 171).

Apparently, this familial sentiment was reciprocated: "Now sahibs much glad with my matter. Mrs. Littledale said to me: 'You seemed to me as my son'” (Galwan, 1923, page 175). The text effectively valorizes an ostensibly parental relationship between servant and sahib, by suggesting that it is characterized by a benevolent desire for reciprocity and exchange among all concerned.

We have argued in this section that Servant of Sahibs utilizes a variety of textual devices to tell an authenticated story appropriate to the requirements of the colonial establishment. By stressing the authentic Native's faith in both the general benevolence and justice of colonial rule, and the specific benefits of colonial labor relations, Rassul Galwan's account confirmed colonizers' more complimentary self-images and challenged arguments against traditional forms of colonial labor that were becoming increasingly dominant in the early decades of the 20th century. The tropes developed in the text are similar to many of those identified by Pratt in her study of imperial travel writing and are familiar to readers of colonial accounts by Younghusband and countless others. By collaborating in the creation of a text that combined an authenticated Native voice and narrative position with a familiar colonial discourse, Rassul Galwan finally demonstrated his appropriateness and got his book published.

Judging from the sketchy evidence of five brief contemporary reviews of the book (none more than 300 words) both the teller and the tale were accepted as authentic. All of the reviews stress Rassul Galwan's impeccable credentials. The Book Review Digest, for example, states that

"The book is written by a Mohammedan [sic] of Kashmir who has worked for many years in the service of English and American travelers in the Himalayas, Central Asia and Tibet. He took care of their caravans, handled their money, bought animals and supplies, hired men, and acted as diplomatic representative for the various sahibs he served" (Knight and James, 1925, page 231).

The New Statesman implies that some of Rassul Galwan's authenticity derives from the distinguished sahibs he served:

"From his boyhood Rassul Galwan has been a carrier for English and American travellers; and he has numbered among his Sahibs such distinguished adventurers as Harold Littledale and Sir Francis Younghusband. That is sufficient guarantee as to the nature of Rassul's travels; it only remains to add that he himself loved adventure as ardently as any of his masters" (Anon., 1924a, page 584).

Reviewers were also inclined to treat Rassul Galwan's story as authentic, and indeed significant. The New Statesman claims that "it was refreshing to get a book of Indian travels told so frankly and so piously by a carrier to Sahibs instead of by the Sahibs themselves... Rassul well repays the effort he asks in the reading" (Anon., 1924a, page 584), and the Boston Transcript notes that "nothing that happened and especially nothing that his sahibs did escaped Rassul's notice. It is a most interesting human document" (Anon., 1924b, page 2). According to The Nation and the Athenaeum "the book gives an interesting glimpse into the mind of an Asiatic of this class... [it] should appeal in particular to all who have served in the East, and have had to do with Asiatic servants" (Anon., 1924c, page 584). Overall, the reviewers authenticate Rassul Galwan and his tale, find the language difficult but worth deciphering, and portray the 
Barretts' intervention as merely editorial (Anon., 1924a; 1924d). Although there is only one explicit reference to the close bond between master and servant (Anon., 1924d, in which Younghusband's introduction is cited), there is no indication that reviewers doubted the text's theme of growth through colonial labor. Nor do reviewers seem to find the text outdated or anachronistic; they seem to accept it as an accurate rendering of a contemporary situation. The reviews also express a sense that Rassul Galwan gives readers some insight into a more mysterious - less accommodative - side of the 'Asian character'. This sense is expressed most clearly in The Nation and the Athenaeum: "Rassul will recall to [those who have had to do with Asiatic servants], and perhaps explain, incidents which at the time seemed rather mysterious" (Anon., 1924c, page 584). We now turn to this more potentially disruptive theme of Servant of Sahibs.

\section{Disrupting colonial labor?}

Having argued that the main themes and textual devices of Servants of Sahibs support and reproduce discourses legitimating coercive colonial labor relations-with the somewhat ambiguous authority of an ostensibly authentic Native voice - we now turn to the ways the text partially subverts its own markers of authenticity and the very labor practices it appears, in the main, to valorize. We have imposed this separation between confirmation and subversion in the hope that it will help simplify and clarify our arguments. However, we recognize its artificiality and complicate it in the concluding section. If the concepts of transculturation, autoethnography, mimicry, and hybridity have any shared heuristic value it is to demonstrate that colonial power and its subaltern subversion-Native authenticity and its dissipation-are constituted through a common subject, situated within a single discursive field, and are in fact continuously subject to a destabilizing poaching by their opposite others. Having offered this disclaimer, we now discuss some intersecting minor themes of disruption that surface amidst the major themes outlined in earlier sections of the paper.

Habermas (1984) identifies claims to authenticity as one of three ways participants in communicative action are able to validate their arguments. For Habermas,

"the validity claim of authentic self expression appears to have a two-fold meaning.

On the one hand, it has the straightforward sense of the speaker's sincerity or nondeceptiveness toward the hearer... . On the other, an authentic self-expression is one which expresses a speaker's real or true needs" (White, 1988, page 147).

What this implies in the context of his social theory, and arguably also in everyday usage, is that speech can only be accepted as authentic if it appears not to be driven by instrumentalist motivations or voiced in a context of unequal power relations. As soon as power and instrumentality are introduced into a speech situation, as they inevitably are, the claim to authenticity loses its strength: the concept, therefore, is inherently contradictory. There are two main sites at which Servants of Sahibs disrupts its own claims to authenticity: the situation of the textual project within Rassul Galwan's life (indicative of the instrumentality of telling the story) and the situation of Rassul Galwan's voice within a colonial discursive field (which raises the issue of power). These intersect in the production of an autoethnographic text and in the ambivalent mimicry and/or tactical hybridity that characterize Rassul Galwan's emergence in the book as a colonial subject.

The question of where the textual project - the production of Servant of Sahibsfits into Rassul Galwan's life emerges as we hear him construct other servants and sahibs as resources for self-advancement. In one telling passage, for example, he recalls his childhood dreams: 
"in head all time in night made rich, made meet with big men and spoke with them, and meet with beautiful girl friends, and found good wife, and wear good clothes and eat good things. And for mother made very good, and see many different countries with sahibs" (Galwan, 1923, page 9; emphasis added).

Later in the narrative, he describes the following conversation among servants:

"We each other said:...'we will find rich money from sahib'. I said among them: 'These sahibs are very big men. We must need do good work, and truth in everything. Because we have much work, this all do not think trouble. We will find good money, and beside that, sahib write our name in his book, and the Government be kind to us", (Galwan, 1923, page 171).

Additionally, in the early section of the book he talks about learning to read and write his own language, and learning to speak other languages, as a way to improve his prospects, and at several points he hints at the instrumental benefits of fluency in several languages, for example when

"the Pathan sepoys said 'Rassul, we are not Pathan. We are coolies before you. You are Pathan and brave man, which you can speak all languages. Therefore we said you are Pathan, and we are coolies" (Galwan, 1923, page 242; emphasis added).

Indeed he indicates that his proficiency in Turki was instrumental in forging an initial profitable relationship with Barrett:

“'You can speak English?' I said: 'Yes sir, I can speak a little'. And the sahib said:

'You can speak Turki?' I said: 'Yes sir'... And then we speaked some Turki. The poor sahib was very glad ... . The poor sahib said to me: 'I like you very much, and you will get good luck with me'. I said: 'Yes, sir'” (Galwan, 1923, page 250).

The impression given by both Rassul Galwan and Younghusband is that his attempt to follow British etiquette, and so on, is also a means to self-advancement. As Younghusband (1923, page x) remarks: "Equally noteworthy [is] his close observation of men and their customs: 'All that I kept in my head', he says after relating the manner in which Englishmen and Chinese officials visited each other".

Seen in this light, Servant of Sahibs is an instrumentalist tale, a narrative of one 'poor boy's' quest to become richer, more respected, and more 'civilized'. At the same time as this professed faith in the civilizing and enriching effect of colonial labor helps construct him as an appropriate Native, it also raises the suspicion that his instrumentalist motives extend to the production of the text itself. It is hard to imagine that a person as admittedly ambitious as Rassul Galwan would not modify his behavior and the content of his narrative to enhance the potential of this writing project to provide instrumental advantages, both immediately in terms of the benefits of intimacy with the sahib, who provides instruction, and in the long term as his fame as the author of a published English-speaking book spreads. As soon as readers suspect this, the text's authenticity is in doubt.

The act of writing and publishing Servant of Sahibs also solidifies Rassul Galwan's mimicry. He becomes the archetypic 'mimic-man', "a colonial subject who will be recognizably the same as the colonizer but still different: "not quite/not white" (Young, 1990, page 147). By writing the book, itself a "miming of the very operation of domination" through which the "identity of colonizer and colonized become curiously elided", he casts his authenticity further in doubt (Young, 1990, page 148). He no longer represents 'real' Natives: he takes guidance from "the King James Bible and a seventeenth century book of travel" (Barrett, 1923a, page xiv) in order to adopt an appropriate writing style, he disagrees with other servants on most matters relating to sahibs, and he speaks in English to Westerners he has never met. The very attributes that give him a voice, and serve instrumental purposes, deprive him of his Native authenticity. In speaking, he loses his subalternity. That this process of mimicry, by 
which "the look of surveillance returns as the displacing gaze of the disciplined" (Bhabha, 1984, page 129) was experienced as unsettling to sahibs is indicated by the Barretts' stern reminder, in the last paragraph of the book's editorial epilogue, that Rassul Galwan was their product and that, whatever his own delusions, his mimicry of European writing was far from perfect: they quote Rassul Galwan as saying

"Sahib said to me: 'Rassul you must remember. I will not let you go from my friendship until you learn English'. Yes that promise got right. At this time by his kindly I learning this my style, which now I written as a book. Not got any wrong in this matter" (Barrett, 1923b, page 279).

By ridiculing Rassul Galwan's gratitude and his pride in his broken English, the Barretts attempt to neutralize the displacing gaze of the disciplined and indeed discipline Rassul Galwan one last time.

These final lines of the book also indicate, one last time, that Rassul Galwan's voice cannot escape its subordinate situation within a colonial discursive field. This disciplining move authenticates Rassul Galwan's subordination and at the same time damages the text's authority as a sincere Native voice. This is apparent in what we have already suggested about Rassul Galwan's instrumental use of the textual project, and of his Western masters. Just as his use of sahibs is the instrumentalist material move of a material subordinate, so his use of an authorial position is an instrumentalist discursive move by a discursive subordinate. At the same time, the suspicion that Rassul Galwan is fabricating an accommodative story for his own advantage in a colonial setting is one important way that his subordinate position disrupts the text's authenticity as a Native affirmation of colonial domination and raises the suspicion that Rassul Galwan is up to more than meets his sponsors' eyes.

Rassul Galwan's mimicry of his colonial masters is another way that his experience of subordination enters the text in a disruptive fashion. The subaltern's attempts to reproduce the discourses of colonialism - to mimic the master-necessarily emerge from their subordinate positioning within the larger discursive field. Thus, the mimicking discourses the colonized redirect to the colonizer are reshaped, distorted, by the experience of subordination. A subaltern experience enters, and introduces an ambivalence into what had seemed to be the coherent and rational voice of power. The extent to which, in Servant of Sahibs, the disrupting effect of imperfect mimicry transforms into a more tactical insertion of "other, repressed knowledges" (Young, 1990, page 148), intended by Rassul Galwan to effect a "strategic reversal of the process of domination" which turns "the gaze of the discriminated back on the eye of power" (Bhabha, 1985, page 154), is impossible to tell. Whether tactical or unwitting, his view from underneath does insert other knowledges into the book, most obviously in the lengthy demonstrations of the arbitrariness and wilful self-indulgence of colonial power as it was practiced on a daily basis.

The most prolonged example of this occurs in the book's final chapter, titled "Testing the sahibs: a drama", which centers almost entirely on servants' attempts to keep abreast of Robert Barrett's unpredictable whims, commands, and abrupt changes of plan, and their subsequent attempts to determine whether this particular sahib will bring them good luck or bad. The chapter includes numerous vignettes, all of which follow the same pattern (as in similar instances in other parts of the book). They begin with Barrett behaving in a seemingly irrational way. Servants attempt briefly and ineffectually to discuss or at least clarify things with their master, but soon merely resign themselves to their inability to change (or predict) the situation. Following resignation is a complex process of completing added work, talking through frustrated hopes, and dealing with the other numerous ramifications and complications servants suffer because of Barrett's whimsy. While they deal with this added burden, they also 
attempt to understand what their master's latest action suggests for their own future in his employ, an effort which ends in uncertainty and anxiety. These anxieties are not resolved until the end of the chapter, with Rassul Galwan's epiphany, during which he concludes that, despite Barrett's idiosyncrasies, he is a kind and just man:

"I felt much better and like to travel with sahib. And then I said: 'Yes, sir. If I go with you then all the servants must come with me'. Sahib said: 'You will get good luck with me... Now I get much happy" (Galwan, 1923, page 277).

But the voice of hybridity has spoken, and the subaltern experience of colonial power as arbitrary, self-indulgent, and unreasonable has been revealed. Barrett, as an American, is not officially part of the British colonial apparatus, although his positioning vis-à-vis locals such as Rassul Galwan implicates him in colonial power. A similar subaltern experience of a more direct and explicit British colonial power surfaces quietly at many other points in the book, as, for example, in the following:

"We were sorry because the sahibs [Lord Dunmore and Major Roche] abused to us and said: 'Why not bring water for tiffen?' We did not know they would take tiffen here, top pass. If had told yesterday, would bring water, but that not tell. Now they abuse to us, and tell us: 'Walk fast till meet water"' (Galwan, 1923, page 59).

Similarly, in citing a conversation with Francis Younghusband:

"I said: 'Sir, all servants got clothes from you. Please give me some'. Sahib said: 'Boy, I have heard you not doing any work. For that, I don't want you any more. I will let you go from here'. I said: 'Sir, I have done very good work. In the camp I have cooked for the men and looked the ponies. You do not know'. Sahib said again: 'I don't want you, you lazy boy'. When I heard that, my felt very sorry, and I said: 'Sir, it is my bad luck. If you do not want me, cannot help'. Sahib said: "Go away'" (Galwan, 1923, age 37).

Again and again, despite Rassul Galwan's later attempts to excuse his masters, and set their behavior within a context of unspecified benevolence, the irresponsibility of colonial power is already revealed.

The major themes of Servant of Sahibs describe the naturalness, benevolence, justice, and mutual benefit of colonial labor relations. But in developing these themes from a position of subordination and subaltern experience Rassul Galwan inserts minor themes of the arbitrariness, unawareness, and wilful self-indulgence of colonial power and the resigned and fearful acquiescence of colonial laborers, both of which distort the impact of the dominant discourse. His attempts to reproduce a colonialist discourse from a subaltern subject position are damaging to the dominant discourse of colonial labor relations, because they discredit the tropes of British benevolence, paternalism, and rationality that underlie that discourse.

In this section we have argued that Servant of Sahibs partially damages both its own markers of authenticity and its defense of colonial labor practices. We have tried to show that the minor themes of disruption that surface in this textual project are not discrete oppositional themes that run parallel to the main themes but rather are intrinsic to the project of mobilizing a subaltern subject position to present an authentic Native voice in support of a colonial discourse of domination. In short, the hazards of using Servant of Sahibs to bolster colonial authority stem from its existence as an autoethnographic public transcript and as an instance of mimicry or hybridity (we cannot say which) within a colonial discursive field.

\section{The unreliability of resistance and accommodation}

The textual sites from which resistance and accommodation to power radiate are shifting, impermanent, unreliable. We conclude in this section by briefly doubting the extent to which the 'other' more typically subaltern knowledges Rassul Galwan inserts 
into the text are able to retain their status as repressed knowledges and by raising the possibility that - although still constituted through a subjectivity forged within a field of British colonial domination - much of what Rassul Galwan has to say that sounds accommodative to British colonialism may be more directly informed and motivated by a context that is only tangentially related to the Native-colonial-labor relations that preoccupy the sponsors of the book.

It is clear that Rassul Galwan is less an authentic indigenous subject than a subject hybridized by the transcultural effects of colonial power. According to Bhabha's conceptualization this hybridized subjectivity is a site from which other denied or repressed knowledges can disrupt dominant discourses and their effects (Bhabha, 1985, page 156). In the previous section we demonstrated that Rassul Galwan does indeed insert other knowledges-minor themes of the arbitrary, cruel, and sadistic exercise of power - into the major, and editorially sanctioned, themes of benevolent European justice and mutually beneficial labor relations. However, given that he was allowed to articulate these other themes explicitly and in detail it is disingenuous to characterize them as repressed or denied. Whatever Rassul Galwan's intentions, it seems the Barretts were content to incorporate the subaltern's other knowledge into the text as a useful complement to the main messages of the book (although one still wonders why so much of what Rassul Galwan wrote about the period after 1901 was edited out). Indeed, it may not serve the purposes of colonialism to present too rational - too communicative - a version of colonial labor relations. Colonialism relies on an ideology (if never the successful practice) of absolute power which it is often useful to represent as benevolent and just. Rassul Galwan's occasional complaining about the arbitrariness and wilfulness of his masters' exertion of power usefully reminds the reader of this absolute power and in so doing makes his overall support of colonial labor relations that much more marvelous and complimentary to his masters. We discuss this recuperation of Rassul Galwan's tactics not as a demonstration of the wily colonizer outwitting the naive subaltern. Rather, we see it as an example of a more general reversal of what Bhabha describes as the ambivalent effects of subaltern hybridity; here, "colonial purposes enter upon the subaltern discourse and estrange the basis of its authority"; here, hybridity is used by the colonizer to become a "strategic reversal of the process of resistance" (adapted from Bhabha, 1985, pages 156 and 154, respectively, emphasis added). It shows, against the implication of much discussion of concepts such as transculturation, hidden transcripts, mimicry, and hybridity, that the disruption achieved by tactically inserting oppositional discursive threads into discourses of domination can never be assumed to be final. There is no closure, empirically or analytically.

Neither are the origins and genealogy of what emerges as the dominant discourse as certain as many discussions of subaltern agency and resistance imply. Rassul Galwan's major themes of European justice and benevolent colonial labor relations were evidently read by Younghusband, the Barretts, and presumably other contemporary Europeans as an authentic Native endorsement of British colonialism; a reading that is easily interpreted as willfully blind to the Native author's subject constitution within a field of colonial domination. However, given that (a) the book was written at a time when the colonial power that dominated Kashmir proper, Ladakh, Baltistan, Gilgit, etc on a daily basis was Dogra and not British, (b) Dogra colonialism is remembered by these populations as much more brutal, unpredictable, and repressive than British colonialism, and (c) Rassul Galwan frequently compares his European masters favorably with what he calls 'Hindu justice', it may be that what the book's sponsors recognized as an authentic Native endorsement of - or at least a willing accommodation to-British policy, actually has its origins as an act of resistance 
against the Dogra administration; an expression of resistance which strategically uses the sponsorship of Europeans to reduce the risk of reprisal and effectively spread the message. ${ }^{(15)}$

The point is not to sanction one interpretation of Rassul Galwan's intentions over another - we are not in a position to know - but rather to endorse the plausibility of an interpretation that locates his apparent support of British colonial labor relations some place other than in a subject position that is either fully colonized, or authentically resistant to colonization. This returns the discussion, finally, to Griffith's assertion that representations of specific indigenous voices as authentic need "to be addressed through their reflection of a larger practice within colonialist discourse, a practice in which the possibilities of subaltern speech are contained by the discourse of the oppressor" (1994, page 71). Our speculations on the genealogy of Rassul Galwan's text suggest that Native authenticity within a field of colonial domination is, indeed, impossible. But they also suggest a more positive conclusion: that just as subaltern ambivalence can be recuperated by the oppressor, so can the possibilities of subaltern speech be enabled (as well as contained) by the oppressor's discourse.

Finally-but not definitively-let us acknowledge Rassul Galwan's accomplishment, however compromised:

"When a line of communication is established between a member of subaltern groups and the circuits of citizenship or institutionality, the subaltern has been inserted into the long road to hegemony. Unless we want to be romantic purists or primitivists about 'preserving subalternity' - a contradiction in terms - this is absolutely to be desired” (Spivak, 1999, page 310).

Acknowledgements. First, our sincere appreciation to the people of Shimshal and Askole, Pakistan, for their frequent pointed reminders that neocolonial and developmentalist power is also arbitrary, self-indulgent, and unreasonable. Second, we would like to thank Martijn van Beek, Kathryn Besio, Nancy Cook, Mike Ripmeester, Alan Sinfield, Sue Spearey, and Tim Youngs for their valuable comments on earlier drafts of the paper. Third, we are most grateful to three anonymous referees for their careful and constructive suggestions. The authors accept responsibility for any errors and omissions that remain.

\section{References}

Adorno R, 1982, "A language of history in Guaman Poma's Nueva Coronica y Buen Gobierno", in From Oral to Written Expression: Native Andean Chronicles of the Early Colonial Period Ed. R Adorno (Syracuse University Press, Syracuse, NY) pp 109- 173

Anderson M, 1993, "Work construed: ideological origins of labor law in British India to 1918", in Dalit Movements and the Meanings of Labor in India Ed. P Robb (Oxford University Press, Delhi) pp $87-120$

Anon., 1924a, "Review of Servant of Sahibs" The New Statesman 28 February, page 584

Anon., 1924b, "Review of Servant of Sahibs" Boston Transcript 24 May, page 2

Anon., 1924c, "Review of Servant of Sahibs" The Nation and the Athenaeum 19 January, page 584

Anon., 1924d, "Review of Servant of Sahibs" The Times Literary Supplement 10 January, page 28

Appadurai A, 1996 Modernity at Large: Cultural Dimensions of Globalization (University of

Minnesota Press, Minneapolis, MN)

Bamzai P, 1987 Socio-economic History of Kashmir (Metropolitan Book Co., New Delhi)

(15) Martijn van Beek discusses another possibility. He suggests that "the audience Galwan intended for the book (rather than the text it contained) is indeed a local, Ladakhi one... in spite of the obvious success of his career in the service of sahibs, Galwan was still from a poor family... [he] sought to enhance his social standing by writing a book in English, the language of foreign and superior power... [he] put himself in the company, indeed in conversation, with the rulers of India, further stressing his position in that modern, colonial world where Ladakhi 'traditional' hierarchy carried little weight" (1998, page 58). At home, in Ladakh, the fact of the book may have mattered more than its content. Not only may different communities receive an autoethnographic text differently, but in this case they may have been receiving quite different things: a book versus a text. 
Barrett K, 1923a, "Editor's introduction", in Servant of Sahibs: A Book to be Read Aloud G R Galwan (W Heffer \& Sons, Cambridge), pp xiii - xvi; reprinted in 1924 by D Appleton, New York, and in 1995 in a limited edition by the author's grandson, M A Galwan

Barrett K, 1923b, "Editor's epilogue", in Servant of Sahibs: A Book to be Read Aloud G R Galwan (W Heffer \& Sons, Cambridge), pp 278 - 279; reprinted in 1924 by D Appleton, New York, and in 1995 in a limited edition by the author's grandson, M A Galwan

Barrett R, Barrett K, 1928 The Himalayan Letters of Gypsy Davy and Lady Ba: Written on Pilgrimage to the High Quiet Places among the Simple People of an Old Folk Tale (Houghton Mifflin, Boston, MA)

Barrett R, Barrett K, 1931 A Yankee in Patagonia: Edward Chace, His Thirty Years There (W Heffer \& Sons, Cambridge)

Behdad A, 1994 Belated Travelers: Orientalism in the Age of Colonial Dissolution (Duke University Press, Durham, NC)

Bhabha H, 1983a, "Difference, discrimination and the discourse of colonialism", in The Politics of Theory Eds F Barker, P Hulme, M Iversen, D Loxley (University of Essex, Colchester, Essex) p $194-211$

Bhabha H, 1983b, "The Other question" Screen 24(6) 18-36

Bhabha H, 1984, "Of mimicry and man: the ambivalence of colonial discourse" October 28 $125-133$

Bhabha H, 1985, "Signs taken for wonders: questions of ambivalence and authority under a tree outside Delhi, May 1817" Critical Inquiry 12144 - 165

Brinkman A, 1868 Wrongs of Cashmere: A Plea for the Deliverance of that Beautiful Country from the Slavery and Oppression from which it is going to Ruin (Thomas Bosworth, London)

Brydon D, 1991, "The White Inuit speaks: contamination as literary strategy", in Past the Last Post: Theorizing Post-colonialism and Post-modernism Eds I Adam, H Tiffen (Harvester Wheatsheaf, New York) pp $191-203$

Fee M, 1989, "Why K.C. Stead didn't like Kerri Hulme's The Bone People: who can write as other?" Australian and New Zealand Studies in Canada $111-32$

Foucault M, 1979, "What is an author?", in Textual Strategies: Perspectives in Post-structuralist Criticism Ed. J Harari (Cornell University Press, Ithaca, NY) pp 141 - 160

Galwan G R, 1923 Servant of Sahibs: A Book to be Read Aloud (W Heffer \& Sons, Cambridge), reprinted in 1924 by D Appleton, New York, and in 1995 in a limited edition by the author's grandson, M A Galwan

Gikandi S, 1996 Maps of Englishness: Writing Identity in the Culture of Colnialism (Columbia University Press, New York)

Griffiths G, 1994, "The myth of authenticity: representation, discourse and social practice", in De-scribing Empire: Post-colonialism and Textuality Eds C Tiffin, A Lawson (Routledge, London) pp $70-85$

Habermas J, 1984 The Theory of Communicative Action: Reason and the Rationalisation of Society (Beacon Press, Boston, MA)

Klor de Alva J, 1992, "Nahua colonial discourse and the appropriation of the (European) other" Archives de Sciences Sociales des Religions 77 15-35

Knight M, James M, 1925 The Book Review Digest: Reviews of 1924 Books (H W Wilson, New York)

Ludden D, 1993, "Orientalist empiricism: transformations of colonial knowledge", in Orientalism and the Postcolonial Predicament Eds C Breckenridge, P van der Veer (University of Pennsylvania Press, Philadelphia, PA) pp $251-278$

MacDonald K I, 1994, "Stages, strikes and snowlines: the use of space in resistance to exploitive labor in a high mountain environment", paper presented at the Annual Meeting of the Canadian Association of Geographers, Waterloo, Ontario, May 1994; copy available from K I MacDonald

MacDonald K I, 1998, "Push and shove: spatial history and the construction of a portering economy in northern Pakistan" Comparative Studies in Society and History 40287 - 317

MacLaren I S, 1995, "The metamorphosis of travellers into authors: the case of Paul Kane", in Critical Issues in Editing Exploration Texts: Papers given at the Twenty-eighth Annual Conference on Editorial Problems, University of Toronto, 6-7 November 1992 Ed. G Warkentin (University of Toronto Press, Toronto) pp 67-107

Metcalf T, 1995 Ideologies of the Raj (Cambridge University Press, Cambridge) 
Paster B, 1989, "Silence and writing: the history of the Conquest", in 1492-1992: Re/Discovering Colonial Writing Eds R Jara, N Spadacnini (The Prisma Institute, Minneapolis, MN) pp $121-164$

Phillips R, 1999, "Sexual politics of authorship: rereading the travels and translations of Richard and Isobel Burton" Gender, Place and Culture 6241 - 257

Pratt M L, 1986, "Scratches on the face of the country: or, what Mr. Barrow saw in the land of the Bushmen", in 'Race', Writing and Difference Ed. L Gates (University of Chicago Press, Chicago, IL) pp $138-162$

Pratt M L, 1992 Imperial Eyes: Travel Writing and Transculturation (Routledge, London)

Pratt M L, 1994, "Transculturation and autoethnography: Peru, 1615/1980", in Colonial Discourse/Postcolonial Theory Eds F Barker, P Hulme, M Iversen (Manchester University Press, Manchester) pp $24-46$

Root D, 1996 Cannibal Culture: Art, Appropriation and the Commodification of Difference (Westview Press, Boulder, CO)

Salomon F, 1982, "Chronicles of the impossible: notes on three Peruvian indigenous historians", in From Oral to Written Expression: Native Andean Chronicles of the Early Colonial Period Ed. R Adorno (Syracuse University Press, Syracuse, NY) pp 9-39

Scott J C, 1990 Domination and the Arts of Resistance: Hidden Transcripts (Yale University Press, New Haven, CT)

Slemon S, 1995, "Unsettling the empire: resistance theory for the Second World", in The Post-colonial Studies Reader Eds B Ashcroft, G Griffiths, H Tiffin (Routledge, London) pp 104-110

Spivak G C, 1985, "Can the subaltern speak? Speculations on widow sacrifice" Wedge 7/8 $120-130$

Spivak G C, 1999 A Critique of Postcolonial Reason: Toward a History of the Vanishing Present (Harvard University Press, Cambridge, MA)

Thorpe R, 1870 Cashmere Misgovernment: An Account of the Economic and Political Oppression of the People of Kashmir by the Maharaja's Government; reprinted in 1973 in Kashmir Papers: British Intervention in Kashmir Ed. S N Gadru (Freethought Literature, Srinagar) $47-96$

Trinh T Minh-ha, 1991 When the Moon Waxes Red: Representation and Cultural Politics (Routledge, London)

van Beek M, 1998, "Worlds apart: autobiographies of two Ladakhi caravaneers compared" Focaal: Tijdschrift voor Antropologie $3251-69$

White S, 1988 The Recent Work of Jürgen Habermas: Reason, Justice and Modernity (Cambridge University Press, Cambridge)

Young R, 1990 White Mythologies: Writing History and the West (Routledge, London)

Younghusband F, 1923, "Introduction", in Servant of Sahibs: A Book to be Read Aloud G R Galwan (W Heffer \& Sons, Cambridge) pp ix - xi; reprinted in 1924 by D Appleton, New York, and in 1995 in a limited edition by the author's grandson, M A Galwan

Yule H, Burnell A C, 1903 Hobson-Jobson: A Glossary of Colloquial Anglo-Indian Words and Phrases, and of Kindred Terms, Etymological, Historical, Geographical and Discursive (John Murray, London) 
